\title{
TITANIUM DIOXIDE NANOPARTICLES SURFACE MODIFIED WITH IMINE AS FILLERS FOR EPOXY RESIN
}

Enis Džunuzović ${ }^{1 *}$, Stefan Ćirjaković ${ }^{1}$, Tijana Kovač², Miloš Tomić2 $^{2}$ Aleksandra Dapčević ${ }^{1}$, Jasna Džunuzović ${ }^{3}$

${ }^{1}$ Faculty of Technology and Metallurgy, University of Belgrade, Belgrade, Serbia

2 Innovation center, Faculty of Technology and Metallurgy, University of Belgrade, Belgrade, Serbia

3 Institute of Chemistry, Technology and Metallurgy, Center of Excellence in Environmental Chemistry and Engineering, University

of Belgrade, Belgrade, Serbia

The surface of anatase $\mathrm{TiO}_{2}$ nanoparticles was modified with in situ synthesized imine, based on 3,4-dihydroxybenzaldehyde and octadecylamine. The modified $\mathrm{TiO}_{2}$ nanoparticles were investigated using FTIR and UV-Vis spectroscopy, which confirmed the formation of the charge transfer complex between imine and surface of $\mathrm{TiO}_{2}$ nanoparticles by the reaction of surface $\mathrm{Ti}$ atoms with hydroxyl groups of a modifying agent. $\mathrm{TiO}_{2}$ nanoparticles modified with imine were further applied as a filler for the preparation of epoxy based nanocomposites. Thermal and mechanical properties of the prepared nanocomposites were examined using the dynamic mechanical analysis, differential scanning calorimetry, thermogravimetric analysis and hardness measurements. The obtained results have shown that modified $\mathrm{TiO}_{2}$ nanoparticles have no significant influence on the glass transition temperature and that they slow down thermo-oxidative degradation of epoxy resin in the first stage and increase hardness of the crosslinked epoxy resin.
(ORIGINAL SCIENTIFIC PAPER) UDC 66.017:678.686

Keywords: epoxy/TiO nanocomposites; surface modification; imine; thermal properties; mechanical properties

\section{Introduction}

Epoxy resins are one of the most popular thermosetting polymers usually applied in construction, electronic, automotive and aerospace industries. The benefits of using epoxy resins are related to their good thermal stability, excellent corrosion, chemical and moisture resistance, good electrical and mechanical properties (high compression and tensile strength, good adhesion properties, good impact resistance, high hardness, low creep), etc. [1]. Furthermore, the high brittleness of these thermosetting polymers can be successfully overcome using adequate fillers. Especially, the incorporation of different inorganic nanoparticles as reinforcing agents in epoxy resins is proved to be a powerful tool to achieve remarkable improvement of various properties of epoxy resins, and consequently to accommodate feature requirements for specific applications. It has been shown that the addition of nanoparticles such as $\mathrm{TiO}_{2}$ [2-16], $\mathrm{SiO}_{2}[17,18]$, nanodiamonds [19,20], graphene [21-23], carbon nanotube [24-26], clay [27,28], ZnO $[29,30]$, etc. can enhance tensile strength, elongation at break, tensile, storage, and flexural modulus, toughness, impact and compression strength, scratch resistance, hardness, adhesive strength, reduce creep rate, improve rheological properties, enhance thermal stability, thermal and electrical conductivity, flame retardancy, dielectric, barrier, anticorrosion, optical and shielding properties of epoxy resins.

Although various nanoparticles are applied as fillers for epoxy resins, special attention has been given to the epoxy nanocomposites based on $\mathrm{TiO}_{2}$ nanoparticles [2-16].
This is not surprising since $\mathrm{TiO}_{2}$ nanoparticles exhibit good optical, catalytic, anticorrosion, dielectric and mechanical properties, high stability, low cost, etc. $\mathrm{TiO}_{2}$ can be found in anatase, rutile and brookite form, wherein anatase and rutile have a tetragonal and brookite orthorhombic (or rhombohedral) crystalline structure $[31,32]$. A number of methods have been used to synthesize $\mathrm{TiO}_{2}$ nanoparticles such as sol-gel, solvothermal, hydrothermal, sonochemical, physical and chemical vapor deposition, electrodeposition, etc. [2,33]. The procedure applied for the synthesis of $\mathrm{TiO}_{2}$ nanostructures has a strong impact on their size, shape and properties [2,32,33].

Prerequisites for the homogenous distribution of $\mathrm{TiO}_{2}$ nanoparticles within the epoxy matrix and the improvement of the properties of epoxy resin after incorporation of $\mathrm{TiO}_{2}$ nanoparticles are good dispersability of nanofiller, as well as enhanced compatibility and interfacial interactions between the polymer matrix and $\mathrm{TiO}_{2}$ nanoparticles. The high surface area of $\mathrm{TiO}_{2}$ nanoparticles facilitates the interactions between nanoparticles and polymer matrix, but also between nanoparticles themselves, leading to the formation of aggregates. However, the expected improvement of polymer properties after inclusion of nanofillers will be omitted if aggregates are present. The most common method used to reduce the aggregation is the surface modification of $\mathrm{TiO}_{2}$ nanoparticles. In addition, by the adequate treatment of the surface of nanoparticles, the compatibility and interfacial in-

\footnotetext{
*Author address: Enis S. Džunuzović, Faculty of Technology and Metallurgy, University of Belgrade,

Karnegijeva 4, 11120 Belgrade, Serbia

E-mail: edzunuzovic@tmf.bg.ac.rs

The manuscript received: November, 12, 2018.

Paper accepted: November, 30, 2018.
} 
teractions between nanofiller and polymer matrix may be enhanced as well. Wang et al. have shown that aggregation of $\mathrm{TiO}_{2}$ nanoparticles in epoxy resin can be prevented by their surface modification with a silane coupling agent [9]. Rubab et al. have used $\mathrm{TiO}_{2}$ nanoparticles surface modified with Y-aminopropyltriethoxysilane to prepare epoxy resin (ER)/ $\mathrm{TiO}_{2}$ nanocomposites with noticeable improved mechanical properties and glass transition temperature $(T g)$, compared to the pure epoxy resin [3]. The reactive amino groups, present on the surface of $\mathrm{TiO}_{2}$ nanoparticles after the modification with the organosilane coupling agent, provided covalent bonding between $\mathrm{TiO}_{2}$ nanoparticles and polymer matrix, leading to the effective reinforcement of epoxy resin with $\mathrm{TiO}_{2}$ nanoparticles. Tao et al. have shown that dispersion of $\mathrm{TiO}_{2}$ nanoparticles and their compatibility with epoxy resin can be increased by grafting poly(glycidyl methacrylate) onto $\mathrm{TiO}_{2}$ nanoparticle surfaces [14,34]. Furthermore, Kobayashi et al. prepared transparent and colorless $\mathrm{ER} / \mathrm{TiO}{ }_{2}$ hybrid films using $\mathrm{TiO}_{2}$ nanoparticles modified with n-octylphosphonic acid [35]. On the other hand, Siddabattuni et al. observed that dielectric properties of $\mathrm{ER} / \mathrm{TiO}_{2}$ nanocomposites depends on the chemical structure of organophosphate ligands applied to modify the surface of $\mathrm{TiO}_{2}$ nanoparticles [36].

In our previous works, we have investigated the influence of the hydrophobic part length of gallic acid esters used for the surface modification of $\mathrm{TiO}_{2}$ nanoparticles, on the properties of commercial epoxy resin (CHS-EPOXY $210 \times 75$ ) $[11,12]$. It was found that prepared nanocomposites exhibit higher $T g$, and better barrier and anticorrosion properties than pure epoxy resin.

Following our previous works, this study is aimed to the investigation of the effect of surface modified $\mathrm{TiO}_{2}$ nanoparticles and their content on thermal and mechanical properties of ER/TiO 2 nanocomposites prepared using commercial epoxy resin (Araldite GT 7071). For this purpose, $\mathrm{TiO}_{2}$ nanoparticles were modified with in situ synthesized imine based on 3,4-dihydroxybenzaldehyde (DHBA) and octadecylamine (ODA). The unmodified $\mathrm{TiO}_{2}$ nanoparticles were examined using transmission electron microscopy (TEM), while modified nanoparticles were investigated by FTIR and UV-Vis spectroscopy. Thermal and mechanical properties of the prepared $\mathrm{ER} / \mathrm{TiO}_{2}$ nanocomposites were tested using dynamic mechanical analysis (DMA), differential scanning calorimetry (DSC), thermogravimetric analysis (TGA) and hardness measurements.

\section{Experimental}

\section{Materials}

Titanium isopropoxide and 3,4-dihydroxybenzaldehyde were obtained from Acros Organics. Nitric acid (65\%) and 2-propanol were purchased from Zorka Pharma, while octadecylamine from Sigma Aldrich. Epoxy resin (Araldite GT 7071) and curing agent (Aradur 115 BD) were obtained from Huntsman Advanced Materials. All chemicals were used as received without further purification.

\section{Synthesis of $\mathrm{TiO}_{2}$ colloid}

The $\mathrm{TiO}_{2}$ colloid was synthesized by hydrolysis of titanium isopropoxide according to the procedure described by O'Regan et al. [37]. The mixture containing $12.5 \mathrm{~mL}$ of titanium isopropoxide and $2.0 \mathrm{~mL}$ of 2-propanol was added from the dropping funnel into $75 \mathrm{~mL}$ of deionized water and vigorously stirred. As a result of the hydrolysis reaction, a white precipitate was formed. Within 10 min of the addition of alkoxide, $0.57 \mathrm{~mL}$ of nitric acid was loaded to the mixture. The obtained mixture was then stirred at $80^{\circ} \mathrm{C}$ for $8 \mathrm{~h}$, allowing 2-propanol to evaporate. In this manner, around $70 \mathrm{~mL}$ of stable $\mathrm{TiO}_{2}$ colloidal solution was obtained.

Surface modification of $\mathrm{TiO}_{2}$ nanoparticles with imine

The surface modification of $\mathrm{TiO}_{2}$ nanoparticles with imine based on DHBA and ODA (DHBA-ODA) was performed according to the following procedure. The solutions of $0.1067 \mathrm{~g}$ of DHBA in $5 \mathrm{~mL}$ of methanol and $0.2085 \mathrm{~g}$ of ODA in $37.5 \mathrm{~mL}$ of chloroform were vigorously mixed with $5 \mathrm{~mL}$ of $\mathrm{TiO}_{2}$ colloid solution, previously diluted with $45 \mathrm{~mL}$ of distilled water. The obtained solution was then left overnight. After that, the lower dark-orange phase containing $\mathrm{TiO}_{2}$ nanoparticles surface modified with DHBA-ODA $\left(\mathrm{TiO}_{2}-\mathrm{ODA}\right)$ was separated from the upper aqueous phase and then slowly, with simultaneous mixing, using the magnetic stirrer, drop-wise added into 100 times larger quantity of methanol. The surface modified $\mathrm{TiO}_{2}$-ODA nanoparticles separated as precipitate, which was then redispersed in chloroform.

Preparation of the $\mathrm{ER} / \mathrm{TiO}_{2}$ nanocomposites

The synthesized $\mathrm{TiO}_{2}$ nanoparticles surface modified with DHBA-ODA were further applied as nanofillers for the preparation of $\mathrm{ER} / \mathrm{TiO}{ }_{2}$ nanocomposites. For that purpose, the commercial epoxy resin Araldite GT 7071 and the curing agent Aradur $115 \mathrm{BD}$ were applied. The weight ratio between the resin and the curing agent were 100:35. The ER/ $\mathrm{TiO}_{2}$-ODA nanocomposites containing 1, 2 and $3 \mathrm{wt} . \%$ of $\mathrm{TiO}_{2}$, calculated with respect to the total mass of the epoxy resin and the curing agent were synthesized by adding the adequate amount of modified nanoparticles, dispersed in chloroform, to the epoxy resin. In order to evaporate chloroform, the mixtures were left at room temperature under the reduced pressure. After that, the adequate amount of xylene (50 wt.\% calculated with respect to the total mass of the epoxy resin and the curing agent) and curing agent were added. For the preparation of pure epoxy resin, in the mixture of Araldite GT 7071 and Aradur 115 BD nanoparticles were not added. The films of pure epoxy resin and $\mathrm{ER} / \mathrm{TiO}_{2}$ nanocomposites were formed by drawing prepared mixtures on glass $(10 \times 10 \times 1 \mathrm{~cm}$ and $15 \times 20 \times 0.3 \mathrm{~cm})$ plates using the $100 \mu \mathrm{m}$ applicator. Films were cured at room temperature for 21 days. Pure epoxy resin and prepared nanocomposites were also cured in Teflon molds $(63 \times 12 \times 2 \mathrm{~mm})$.

Characterization of unmodified and surface modified $\mathrm{TiO}_{2}$ nanoparticles

The size and shape of unmodified $\mathrm{TiO}_{2}$ nanoparticles were determined using TEM (JEOL-1200EX). The size dis- 
tribution of $\mathrm{TiO}_{2}$ nanoparticles was obtained using Image $\mathrm{J}$ software. FTIR spectra of dry unmodified and modified $\mathrm{TiO}_{2}$ nanoparticles in the form of $\mathrm{KBr}$ pellets were recorded using a Bomem MB-102 FTIR spectrophotometer. Perkin-Elmer Lambda-5 UV-Vis spectrometer was applied to record the absorption spectra of unmodified and surface modified $\mathrm{TiO}_{2}$ nanoparticles.

\section{Characterization of the $\mathrm{ER} / \mathrm{TiO}_{2}$ nanocomposites}

A dynamic mechanical analysis of the synthesized samples was performed using TA Instruments SDT Q600 operating in the temperature sweep mode. The temperature dependences of the storage $\left(G^{\prime}\right)$ and loss $\left(G^{\prime \prime}\right)$ modulus and loss factor $(\tan \delta$ ) of cured pure epoxy resin and prepared nanocomposites were determined in the temperature range $25150^{\circ} \mathrm{C}$, at the frequency of $1 \mathrm{~Hz}$ and deformation of $0.1 \%$. Before DMA measurements, the examined samples were removed from Teflon molds and dried in a vacuum oven until the constant mass was reached. DSC measurements were performed on Perkin-Elmer DSC-2 instrument in a nitrogen atmosphere, at a heating and cooling rate of $20^{\circ} \mathrm{C} / \mathrm{min}$. A thermogravimetric analysis (TGA) was performed using the SDT Q600 (TA Instruments) thermogravimetric analyzer. The samples (about $5 \mathrm{mg}$ ) were run from 30 to $600^{\circ} \mathrm{C}$ at the heating rate of $10{ }^{\circ} \mathrm{C} / \mathrm{min}$ in an air flow $\left(0.1 \mathrm{dm}^{3} \mathrm{~min}^{-1}\right)$.

The König pendulum hardness of dried films drawn on glass plates was determined using BYK-Gardner tester, as an average value of three measurements. The thickness of the examined dried films was $22 \pm 3 \mu \mathrm{m}$.



Figure 1. TEM image of prepared $\mathrm{TiO}_{2}$ nanoparticles

\section{Results and discussion}

Properties of unmodified and surface modified $\mathrm{TiO}_{2}$ nanoparticles

$\mathrm{TiO}_{2}$ nanoparticles were prepared by acid catalyzed hydrolysis of the titanium isopropoxide precursor. According to the TEM results, the average diameter of prepared nanoparticles is $3.9 \pm 0.9 \mathrm{~nm}$ (Figure 1). This is in accordance with the X-ray diffraction (XRD) results presented elsewhere, where it was shown that synthesized $\mathrm{TiO}_{2}$ nanoparticles are in an anatase crystal form with a coherent domain size of around $3.6 \mathrm{~nm}$ [38].

In order to enable the transfer of the synthesized nanofiller from the aqueous to the organic phase, $\mathrm{TiO}_{2}$ nanoparticles were surface modified with in situ synthesized imine (DHBA-ODA), based on DHBA and ODA (Figure 2). During the modification reactions, the charge transfer (CT) complex was formed between imine and surface of $\mathrm{TiO}_{2}$ nanoparticles by the reaction of surface $\mathrm{Ti}$ atoms with hydroxyl groups of the modifying agent, causing the appearance of the intense dark-orange color of prepared dispersions.

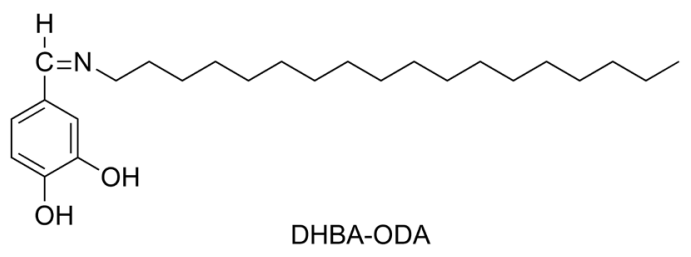

Figure 2. The chemical structure of DHBA-ODA

The chemisorption of DHBA-ODA on the surface of $\mathrm{TiO}_{2}$ colloid and CT complex formation was confirmed by FTIR and UV-Vis spectroscopy. FTIR spectra of DHBA, ODA, surface modified $\mathrm{TiO} 2$ nanoparticles and dry $\mathrm{TiO}_{2}$ colloid are given in Figure 3. In the FTIR spectra of ODA, several characteristic bands can be observed: the bands at 3430 and $3332 \mathrm{~cm}^{-1}$ originate from the $\mathrm{N}-\mathrm{H}$ stretching vibrations, the bands at around 2950 and $2870 \mathrm{~cm}^{-1}$ and at around 2920 and $2850 \mathrm{~cm}^{-1}$ are assigned to the asymmetric and symmetric $\mathrm{C}-\mathrm{H}$ stretching vibrations of methyl and methylene groups, respectively, the band at around $1615 \mathrm{~cm}^{-1}$ corresponds to the $\mathrm{N}-\mathrm{H}$ bending vibration of the primary amine, the band at around $1465 \mathrm{~cm}^{-1}$ is ascribed to the $\mathrm{C}-\mathrm{H}$ bending vibration of the methylene group, while the band at around $723 \mathrm{~cm}^{-1}$ is ascribed to the rocking vibration of more than three methylene groups in the normal hydrocarbon chain. In the FTIR spectra of $\mathrm{TiO}_{2}$ nanoparticles surface modified with DHBA-ODA ( $\mathrm{TiO}_{2}-\mathrm{ODA}$ ) the bands at around 3331 and $3233 \mathrm{~cm}^{-1}$, related to the stretching vibrations of aldehyde phenolic $-\mathrm{OH}$ groups, and the bands at around 1389 and 1192 $\mathrm{cm}^{-1}$, ascribed to the bending vibrations of phenolic $-\mathrm{OH}$ groups, are clearly absent. The intensity of the band at around $1296 \mathrm{~cm}^{-1}$, assigned to the stretching vibrations of phenolic $-\mathrm{OH}$ groups, is reduced and the band became much broader and probably overlapped with the band corresponding to the stretching vibrations of $\mathrm{C}-\mathrm{N}$ bond at $1331 \mathrm{~cm}^{-1}$, which shifted to higher frequencies due to the resonant effect of the benzene ring. A band at around $1645 \mathrm{~cm}^{-1}$, assigned to the stretching vibration of $\mathrm{C}=\mathrm{N}$ bond, and a band at $1576 \mathrm{~cm}^{-1}$, ascribed to the stretching vibration of aromatic ring, can also be observed in the FTIR spectra of $\mathrm{TiO}_{2}-\mathrm{ODA}$ nanoparticles. 
These results indicate that imine DHBA-ODA was formed during the modification of $\mathrm{TiO}_{2}$ nanoparticles, and that it was chemisorbed on the surface of $\mathrm{TiO}_{2}$ through their two adjacent $-\mathrm{OH}$ phenolic groups of the aldehyde residue, leading to the formation of bridging complexes with Ti atoms on the surface $[38,39]$.

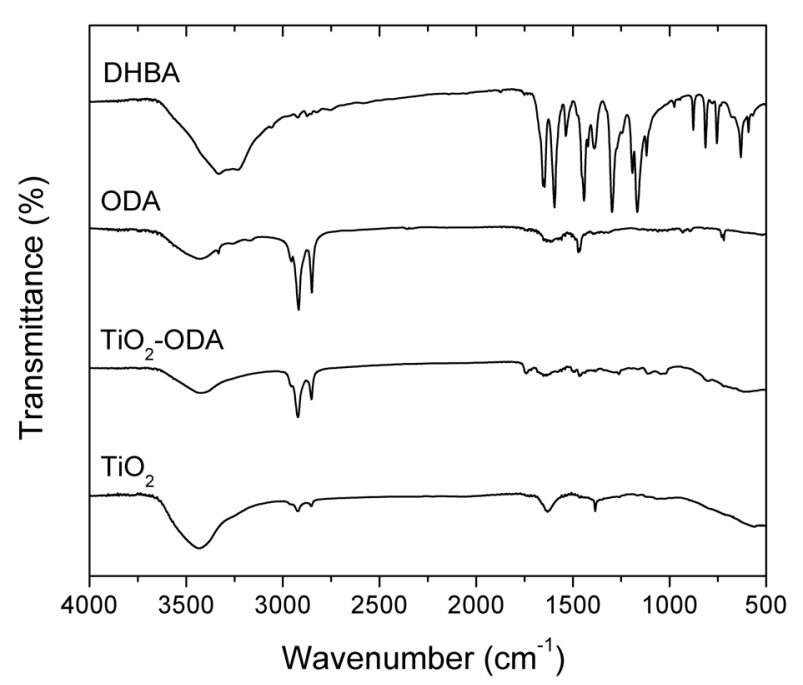

Figure 3. FTIR spectra of DHBA, ODA, surface modified $\mathrm{TiO}_{2}$ nanoparticles and dry $\mathrm{TiO}_{2}$ colloid

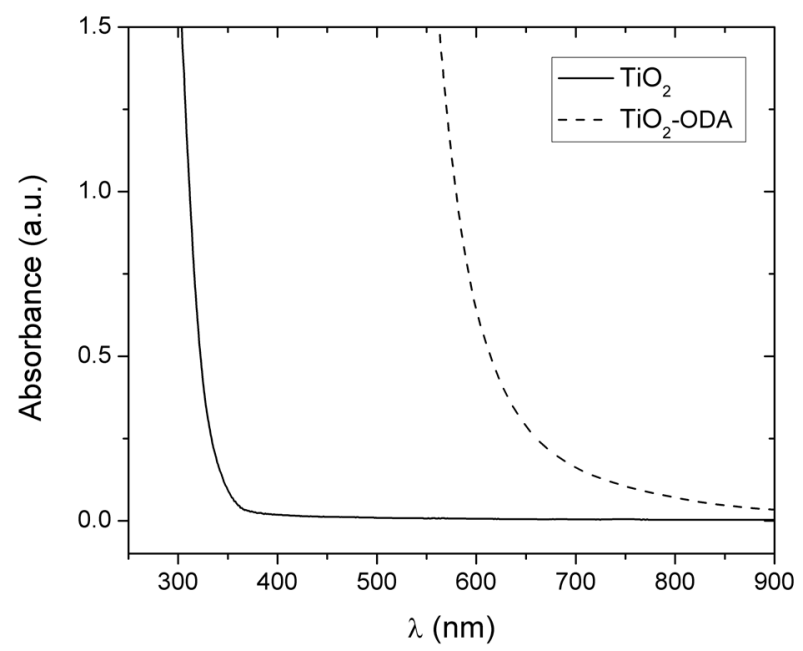

Figure 4. The absorption spectra of aqueous $\mathrm{TiO}_{2}$ colloid solution and surface modified $\mathrm{TiO}_{2}$ nanoparticles in chloroform

The formation of the CT complex due to the chemisorption of DHBA-ODA on the surface of $\mathrm{TiO}_{2}$ nanoparticles was also confirmed by UV-Vis spectroscopy (Figure 4). As it can be observed from the results given in Figure 4 , the absorption spectrum of $\mathrm{TiO}_{2}$ nanoparticles surface modified with DHBA-ODA are red shifted in comparison to the absorption spectrum of $\mathrm{TiO}_{2}$ colloid. The shift of the absorption spectrum of $\mathrm{TiO}_{2}$-ODA for more than 200 $\mathrm{nm}$ towards higher wavelengths occurred as a consequence of the CT complex formation between imine and nanocrystalline $\mathrm{TiO}_{2}$ [38].

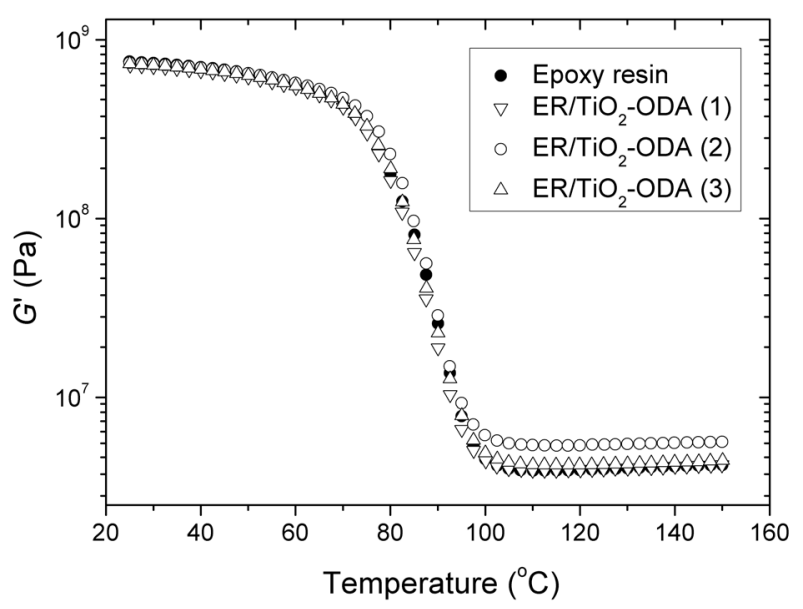

Figure 5. Temperature dependences of the storage modulus $\left(G^{\prime}\right)$ of cured pure epoxy resin and prepared nanocomposites

\section{Properties of ER/TiO ${ }_{2}$ nanocomposites}

$\mathrm{TiO}_{2}$ nanoparticles surface modified with DHBA-ODA were used as nanofillers, while commercially available solid epoxy resin (Araldite GT 7071), designed for the application in high performance protective and decorative coatings, was used as polymer matrix for the synthesis of $\mathrm{ER} / \mathrm{TiO}_{2}$ nanocomposites. In order to investigate the influence of the content of modified $\mathrm{TiO}_{2}$ nanoparticles on the properties of prepared materials, ER/TiO ${ }_{2}^{-}$ ODA nanocomposites were prepared using 1,2 and 3 wt.\% of nanoparticles.

Using DMA, the influence of the surface modified $\mathrm{TiO}_{2}$ nanofillers on the dynamic mechanical properties was explored. The temperature dependences of the storage modulus $\left(G^{\prime}\right)$, loss modulus $\left(G^{\prime \prime}\right)$ and loss factor (tan $\delta$ ) of cured pure epoxy resin and prepared nanocomposites are presented in Figures 5, 6 and 7, respectively. From the results given in Figure 5, three regions of the viscoelastic behavior characteristic for the crosslinked polymers can be observed: the glassy region, the glass transition region and the rubbery plateau region. In the glassy region, $G^{\prime}$ of nanocomposites shows no significant difference compared to the $G^{\prime}$ of pure epoxy resin. Furthermore, $G^{\prime}$ of all examined samples in the glassy region is for one order of magnitude higher than loss modulus (Figure 6), which indicates that during deformation of the samples at low temperatures more energy is saved than lost. In the glass transition region, $G$ ' of pure epoxy resin and prepared nanocomposites sharply decreases due to the increased movement of the polymer chains associated with the glass transition, while in the rubbery plateau region $\left(>100^{\circ} \mathrm{C}\right)$ the flow of the samples is disabled because of the presence of chemical crosslinking. Since $G^{\prime}$ values in the rubbery plateau region are temperature independent and proportional to the crosslinking density, from DMA curves presented in Figure 5 and values of $G^{\prime}$ at $120^{\circ} \mathrm{C}$ listed in Table 1, it can be concluded that there is no significant difference between the crosslinking density of prepared samples, except in the case of sample $\mathrm{ER} / \mathrm{TiO}_{2}-\mathrm{ODA}(2)$ which has slightly higher $G$ ', i.e. a higher crosslinking density. 


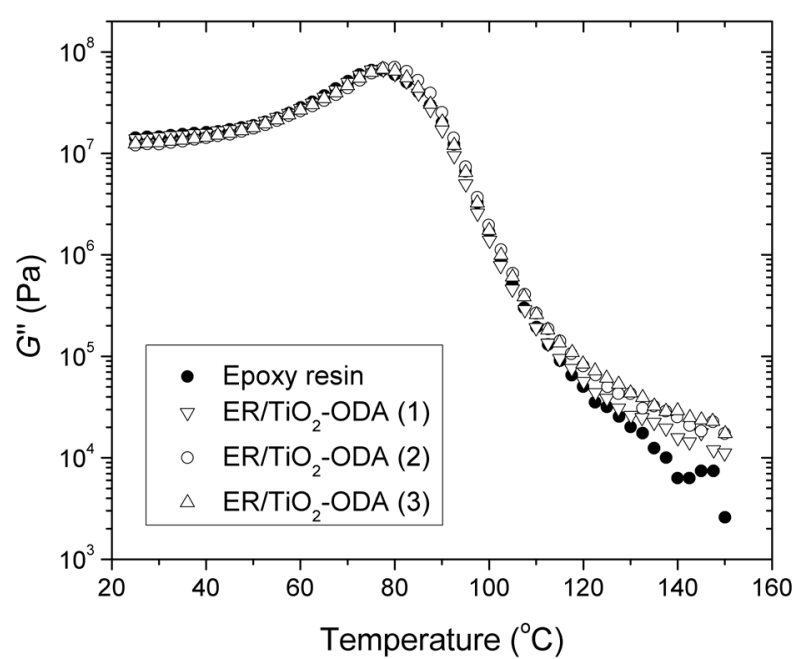

Figure 6. Temperature dependences of the loss modulus ( $\left.G^{\prime \prime}\right)$ of cured pure epoxy resin and prepared nanocomposites

Table 1. DMA and DSC results for pure epoxy resin and prepared nanocomposites

\begin{tabular}{|c|c|c|c|c|}
\hline Sample & $\begin{array}{l}\mathrm{G}^{\prime} \cdot 10^{-6}, \mathrm{MPa} \\
\text { (at } 120^{\circ} \mathrm{C} \text { ) }\end{array}$ & $T_{g}\left(G^{\prime \prime}\right),{ }^{\circ} \mathrm{C}$ & $T_{\mathrm{g}}(\tan \delta),{ }^{\circ} \mathrm{C}$ & $T_{\mathrm{g}}$ (DSC), ${ }^{\circ} \mathrm{C}$ \\
\hline Epoxy resin & 3.9 & 76 & 93 & 81 \\
\hline $\mathrm{ER} / \mathrm{TiO}_{2}-\mathrm{ODA}(1)$ & 3.9 & 77 & 91 & 77 \\
\hline $\mathrm{ER} / \mathrm{TiO}_{2}-\mathrm{ODA}(2)$ & 5.4 & 80 & 92 & 78 \\
\hline $\mathrm{ER} / \mathrm{TiO}_{2}-\mathrm{ODA}(3)$ & 4.2 & 77 & 92 & 77 \\
\hline
\end{tabular}

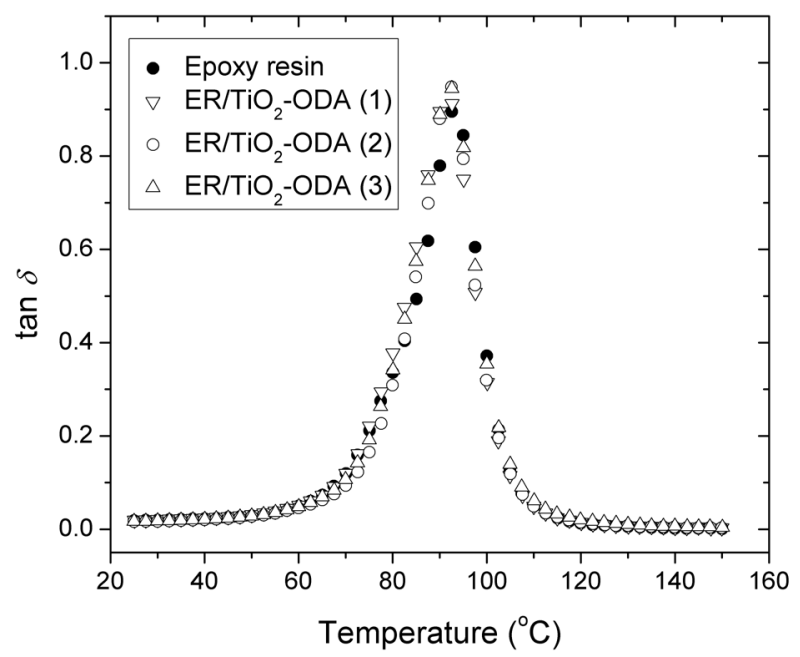

Figure 7. Temperature dependences of the loss factor $(\tan \delta)$ of cured pure epoxy resin and prepared nanocomposites

According to the DMA results shown in Figure 6, it can be observed that temperature dependences of loss modulus are similar for all investigated samples in the whole examined temperature region. Glass transition temperatures $(\mathrm{Tg})$ of the prepared samples, determined as the temperature of the $G^{\prime \prime}$ peak, are listed in Table 1. From the obtained results, it can be seen that the addition of surface modified $\mathrm{TiO}_{2}$ nanoparticles into epoxy resin, and the increase of their content from 1 to $3 \mathrm{wt} . \%$ have no significant impact on the $T g$ of epoxy resin. Similar can be concluded from the tan $\delta$ temperature dependences presented in Figure 7 and $T g$ values of the investigated samples, determined as the temperature of the $\tan \delta$ peak, listed in Table 1. Namely, in Figure 7 only one peak can be observed in the tan $\delta$ temperature dependences, belonging to the main relaxation $\alpha$-process, corresponding to the glass transition of the epoxy resin. Furthermore, since the widths of the tan $\delta$ peaks are similar for all samples, it can be concluded that all samples have approximately the same network homogeneity.

The influence of $\mathrm{TiO}_{2}$ nanoparticles surface modified with DHBA-ODA on the glass transition temperature of nanocomposites was also investigated by DSC. The glass transition temperature of the examined samples was determined as the midpoint of the glass transition event. DSC thermograms of the investigated samples are given in Figure 8, while determined $T g$ values are listed in Table 1. It can be observed that $T g$ values slightly decreased after the addition of surface modified $\mathrm{TiO}_{2}$ nanoparticles into epoxy resin, and show no dependence on the filler content, indicating the existence of weak interactions between $\mathrm{TiO}_{2}$ nanoparticles and polymer matrix.

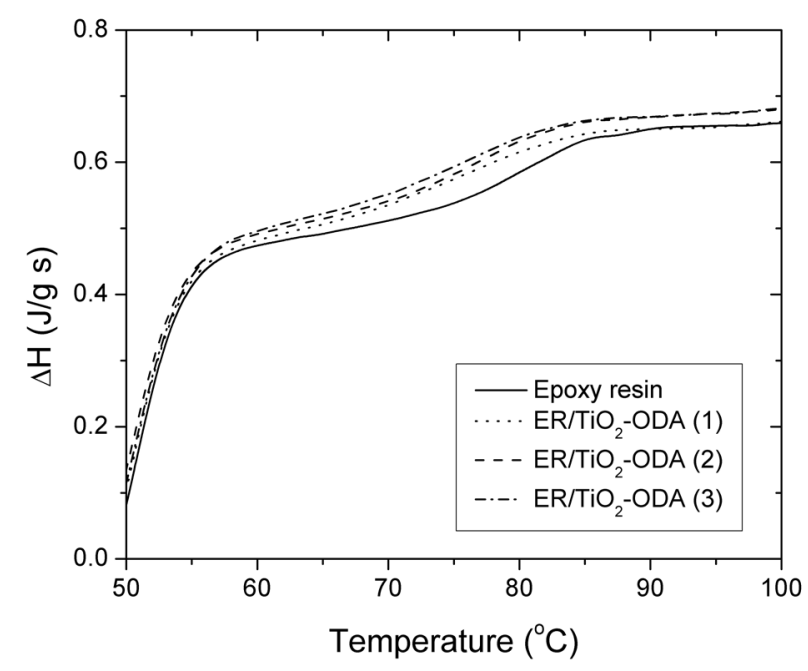

Figure 8. DSC curves of pure epoxy resin and prepared nanocomposites

The influence of the surface modified $\mathrm{TiO}_{2}$-ODA nanoparticles on the thermo-oxidative stability of epoxy resin and $\mathrm{ER} / \mathrm{TiO}_{2}$-ODA nanocomposites was investigated by non-isothermal thermogravimetry performed in air. The thermogravimetric (TG) and differential thermogravimetric (DTG) curves obtained for all examined samples are shown in Figure 9. The thermo-oxidative degradation of all examined samples starts at about $250^{\circ} \mathrm{C}$, indicating that incorporation of $\mathrm{TiO}_{2}-\mathrm{ODA}$ nanoparticles in epoxy matrix has no influence on the beginning of its thermooxidative decomposition. The obtained DTG curves have three peaks. The intensity of the first two peaks is lower for nanocomposites than for the pure ER, implying that 
$\mathrm{TiO}_{2}$-ODA nanoparticles slow down the thermo-oxidative degradation of ER in the examined temperature region. In the last stage (over $500{ }^{\circ} \mathrm{C}$ ), the weight loss rate of nanocomposites is higher than for the pure ER.

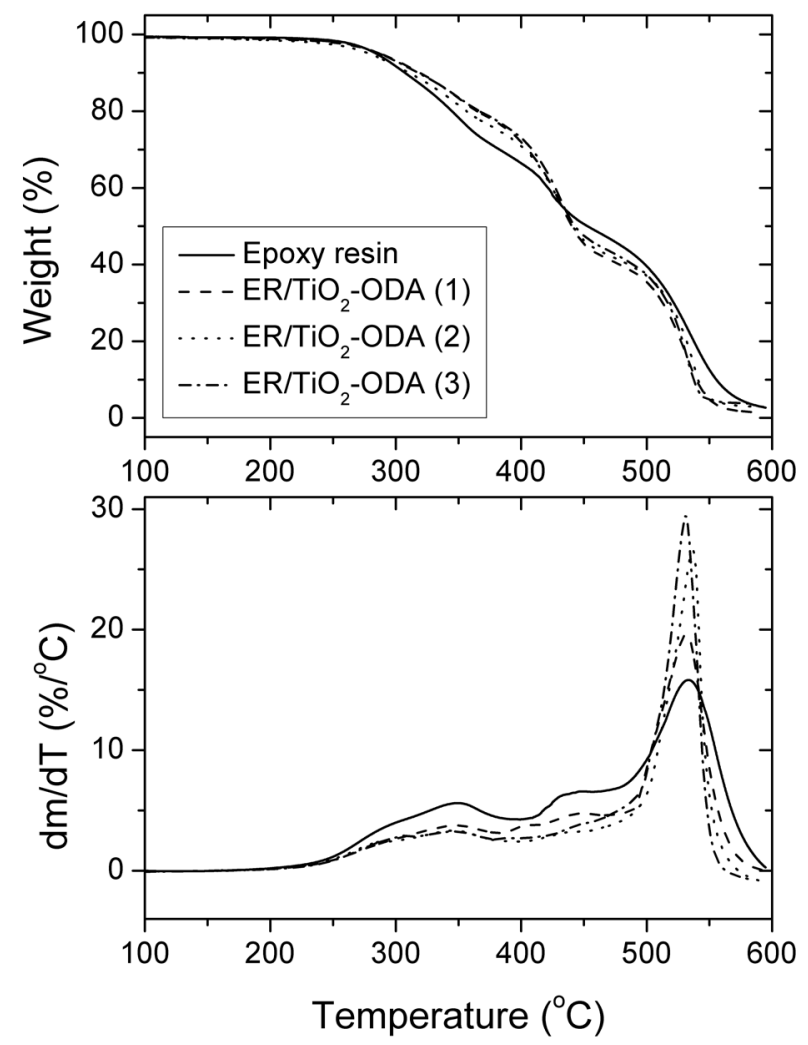

Figure 9. TG and DTG curves of cured pure epoxy resin and prepared nanocomposites obtained in air

The hardness of pure epoxy resin and prepared nanocomposites was determined using König pendulum and the obtained values are listed in Table 2 . From the obtained results, it can be concluded that the addition of 1 wt. $\%$ of $\mathrm{TiO}_{2}$ nanoparticles surface modified with DHBA-ODA into epoxy resin induces no changes in the hardness. However, further increase of the $\mathrm{TiO}_{2}-\mathrm{ODA}$ content led to the slight improvement of the König hardness, since $\mathrm{TiO}_{2}$ nanoparticles have higher hardness than pure epoxy resin.

Table 2. Values of the König hardness of pure epoxy resin and prepared nanocomposites

\begin{tabular}{|c|c|}
\hline Sample & König hardness, s \\
\hline Epoxy resin & 186 \\
\hline $\mathrm{ER} / \mathrm{TiO}_{2}-\mathrm{ODA}(1)$ & 186 \\
\hline $\mathrm{ER} / \mathrm{TiO}_{2}-\mathrm{ODA}(2)$ & 192 \\
\hline $\mathrm{ER} / \mathrm{TiO}_{2}-\mathrm{ODA}(3)$ & 193 \\
\hline
\end{tabular}

\section{Conclusion}

Spherical anatase $\mathrm{TiO}_{2}$ nanoparticles with the average diameter of $3.9 \pm 0.9 \mathrm{~nm}$ were prepared using acid catalyzed hydrolysis of the titanium isopropoxide precursor. $\mathrm{TiO}_{2}$ nanoparticles were then surface modified with imine based on 3,4-dihydroxybenzaldehyde and octadecylamine. The chemisorption of DHBA-ODA on the surface of $\mathrm{TiO}_{2}$ nanoparticles and charge transfer complex formation through the reaction of surface $\mathrm{Ti}$ atoms with hydroxyl groups of the modifying agent were confirmed by FTIR and UV-Vis spectroscopy.

$\mathrm{TiO}_{2}$ nanoparticles surface modified with imine and commercially available solid epoxy resin were used for the preparation of epoxy based nanocomposites. The influence of the surface modified $\mathrm{TiO}_{2}$ nanoparticles and their content on thermal and mechanical properties of nanocomposites was investigated. DMA results revealed that all samples had the approximately same network homogeneity and that the sample $\mathrm{ER} / \mathrm{TiO}_{2}-\mathrm{ODA}$ (2) had a slightly higher crosslinking density than other examined nanocomposites and pure epoxy resin. Furthermore, the obtained DMA and DSC results showed that the addition of $\mathrm{TiO}_{2}$ nanoparticles surface modified with imines into epoxy resin had no significant impact on the $\mathrm{Tg}$ of epoxy resin. These results indicate the existence of weak interactions between $\mathrm{TiO}_{2}$ nanoparticles and polymer matrix.

According to the TGA, the incorporation of $\mathrm{TiO}_{2}-\mathrm{ODA}$ nanoparticles in epoxy matrix has no influence on the beginning of its thermo-oxidative decomposition. The intensity of the first two DTG peaks is lower for nanocomposites than for pure ER, implying that $\mathrm{TiO}_{2}-\mathrm{ODA}$ nanoparticles slow down the thermo-oxidative degradation of ER in the examined temperature region.

The addition of $1 \mathrm{wt} \%$ of $\mathrm{TiO}_{2}$ nanoparticles surface modified with DHBA-ODA into epoxy resin showed no influence on the hardness. On the other hand, a further increase of the $\mathrm{TiO}_{2}$-ODA content led to a slight hardness improvement.

\section{Acknowledgment}

This work was financially supported by the Ministry of Education, Science and Technological Development of the Republic of Serbia (research project number: 172062).

\section{List of symbols and abbreviations}

FTIR - Fourier transform infrared

UV-Vis - Ultraviolet-visible

TEM - transmission electron microscopy

DMA - dynamic mechanical analysis

DSC - differential scanning calorimetry

XRD - X-ray diffraction

ER - epoxy resin

DHBA - dihydroxybenzaldehyde 
ODA - octadecylamine

OA - oleylamine

DHBA-ODA - imine based on DHBA and ODA

DHBA-OA - imine based on DHBA and OA

CT - charge transfer

$\mathrm{Tg}$ - glass transition temperature

$G^{\prime}$ - storage modulus

$G^{\prime \prime}$ - loss modulus

$\tan \delta$ - loss factor

TGA - thermogravimetric analysis

\section{References}

[1] C. A. May, Epoxy Resins Chemistry and Technology, Marcel Dekker, New York, 1988.

[2] D. Pinto, L. Bernardo, A. Amaro, S. Lopes, Mechanical properties of epoxy nanocomposites using titanium dioxide as reinforcement - A review, Construction and Building Materials, 95 (2015) 506-524.

[3] Z. Rubab, A. Afzal, H. M. Siddiqi, S. Saeed, Augmenting thermal and mechanical properties of epoxy thermosets: The role of thermally-treated versus surface-modified $\mathrm{TiO}_{2}$ nanoparticles, Materials Express, 4(1) (2014) 54-64.

[4] A. Chatterjee, M. S. Islam, Fabrication and characterization of $\mathrm{TiO}_{2}$-epoxy nanocomposite, Materials Science and Engineering A, 487 (2008) 574-585.

[5] M. Sangermano, G. Malucelli, E. Amerio, R. Bongiovanni, A. Priola, A. Di Gianni, B. Voit, G. Rizza, Preparation and characterization of nanostructured $\mathrm{TiO}_{2}$ /epoxy polymeric films, Macromolecular Materials and Engineering, 291 (2006) 517-523.

[6] H. A. Al-Turaif, Effect of nano $\mathrm{TiO}_{2}$ particle size on mechanical properties of cured epoxy resin, Progress in Organic Coatings, 69 (2010) 241-246.

[7] B. Wetzel, P. Rosso, F. Haupert, K. Friedrich, Epoxy nanocomposites - fracture and toughening mechanisms, Engineering Fracture Mechanics, 73 (2006) 2375-2398.

[8] D. Morselli, F. Bondioli, M. Sangermano, I. Roppolo, M. Messori, Epoxy resins reinforced with $\mathrm{TiO}_{2}$ generated by nonhydrolytic sol-gel process, Journal of Applied Polymer Science, 131 (2014) 40470-40478.

[9] Y. Wang, Q.-Q. Ni, Y. Zhu, T. Natsuki, Fabrication of functionally graded nano- $\mathrm{TiO}_{2}$-reinforced epoxy matrix composites, Polymer Composites, 35 (2014) 557-563.

[10] H. Shi, F. Liu, L. Yang, E. Han, Characterization of protective performance of epoxy reinforced with nanometer-sized $\mathrm{TiO}_{2}$ and $\mathrm{SiO}_{2}$, Progress in Organic Coatings, 62 (2008) 359-368.

[11] T. S. Radoman, J. V. Džunuzović, K. B. Jeremić, B. N. Grgur, D. S. Miličević, I. G. Popović, E. S. Džunuzović, Improvement of epoxy resin properties by incorporation of TiO2 nanoparticles surface modified with gallic acid esters, Materials and Design, 62 (2014) 158-167.

[12] T. S. Radoman, N. Terzić, P. M. Spasojević, J. V. Džunuzović, A. D. Marinković, K. B. Jeremić, E. S. Džunuzović, Synthesis and characterization of the surface modified titanium dioxide/epoxy nanocomposites, Advanced Technologies, 4(1) (2015) 7-15.

[13] P. K. Ghosh, A. Pathak, M. S. Goyat, S. Halder, Influence of nanoparticle weight fractionon morphology and thermal propertiesof epoxy/ $\mathrm{TiO}_{2}$ nanocomposite, Journal of Reinforces Plastics and Composites, 31(17) (2012) 11801188.
[14] P. Tao, A. Viswanath, Y. Li, R. W. Siegel, B. C. Benicewicz, L. S. Schadler, Bulk transparent epoxy nanocomposites filled with poly(glycidyl methacrylate) brush-grafted TiO2 nanoparticles, Polymer, 54 (2013) 1639-1646.

[15] Y.-Y. Yu, Y.-C. Rao, C.-C. Chang, Preparation and characterization of highly transparent epoxy/inorganic nanoparticle hybrid thin films, Thin Solid Films, 546 (2013) 236-241.

[16] J. Landwehr, R. Fader, M. Rumler, M. Rommel, A. J. Bauer, L. Frey, B. Simon, B. Fodor, P. Petrik, A. Schiener, B. Winter, E. Spiecker, Optical polymers with tunable refractive index for nanoimprint technologies, Nanotechnology, 25 (2014) 505301-505310.

[17] P. Rosso, L. Ye, K. Friedrich, S. Sprenger, A toughened epoxy resin by silica nanoparticle reinforcement, Journal of Applied Polymer Science, 100 (2006) 1849-1855.

[18] X. Shi, T. A. Nguyen, Z. Suo, Y. Liu, R. Avci, Effect of nanoparticles on the anticorrosion and mechanical properties of epoxy coating, Surface \& Coatings Technology, 204 (2009) 237-245.

[19] V. N. Mochalin, I. Neitzel, B. J. M. Etzold, A. Peterson, G. Palmese, Y. Gogotsi, Covalent incorporation of aminated nanodiamond into an epoxy polymer network, ACS Nano, 5 (2011) 7494-7502.

[20] I. Neitzel, V. Mochalin, I. Knoke, G. R. Palmese, Y. Gogotsi, Mechanical properties of epoxy composites with high contents of nanodiamond, Composites Science and Technology, 71 (2011) 710-716.

[21] M. A. Rafiee, J. Rafiee, Z. Wang, H. Song, Z.-Z. Yu, N. Koratkar, Enhanced mechanical properties of nanocomposites at low graphene content, ACS Nano, 3 (2009) 3884-3890.

[22] J. Wei, T. Vo, F. Inam, Epoxy/graphene nanocomposites - processing and properties: a review, RSC Advances, 5 (2015) 73510-73524.

[23] M. Seong, D. S. Kim, Effects of facile aminefunctionalization on the physical properties of epoxy/ graphene nanoplatelets nanocomposites, Journal of Applied Polymer Science, 132 (2015) 42269-42275.

[24] J. A. Kim, D. G. Seong, T. J. Kang, J. R. Youn, Effects of surface modification on rheological and mechanical properties of CNT/epoxy composites, Carbon, 44 (2006) 1898-1905.

[25] F. Xie, S. Qi, R. Yang, D. Wu, High thermal conductive m-xylylenediamine functionalized multiwall carbon nanotubes/epoxy resin composites, Journal of Applied Polymer Science, 132 (2015) 41255-41263.

[26] J. Chang, G. Liang, A. Gu, S. Cai, L. Yuan, The production of carbon nanotube/epoxy composites with a very high dielectric constant and low dielectric loss by microwave curing, Carbon, 50 (2012) 689-698.

[27] A. A. Azeez, K. Y. Rhee, S. J. Park, D. Hui, Epoxy clay nanocomposites - processing, properties and applications: A review, Composites Part B, 45 (2013) 308320.

[28] A. Di Gianni, E. Amerio, O. Monticelli, R. Bongiovanni, Preparation of polymer/clay mineral nanocomposites via dispersion of silylated montmorillonite in a UV curable epoxy matrix, Applied Clay Science, 42 (2008) 116-124.

[29] B. Ramezanzadeh, M. M. Attar, Studying the corrosion resistance and hydrolytic degradation of an epoxy coating containing $\mathrm{ZnO}$ nanoparticles, Materials Chemistry and Physics, 130 (2011) 1208- 1219.

[30] S. Moussa, F. Namouchia, H. Guermazi, Elaboration, 
structural and optical investigations of ZnO/epoxy nanocomposites, The European Physical Journal Plus, 130 (2015) 152-160.

[31] O. Carp, C. L. Huisman, A. Reller, Photoinduced reactivity of titanium dioxide, Progress in Solid State Chemistry, 32 (2004) 33-177.

[32] S. Yang, N. Huang, Y. M. Jin, H. Q. Zhang, Y. H. Su, H. G. Yang, Crystal shape engineering of anatase $\mathrm{TiO}_{2}$ and its biomedical applications, CrystEngComm, 17 (2015) 6617-6631.

[33] X. Chen, S. S. Mao, Titanium dioxide nanomaterials: synthesis, properties, modifications, and applications, Chemical Reviews, 107 (2007) 2891-2959.

[34] P. Tao, Y. Li, A. Rungta, A. Viswanath, J. Gao, B. C. Benicewicz, R. W. Siegel, L. S. Schadler, $\mathrm{TiO}_{2}$ nanocomposites with high refractive index and transparency, Journal of Materials Chemistry, 21 (2011) 18623-18629.

[35] M. Kobayashi, H. Saito, B. Boury, K. Matsukawa, Y. Sugahara, Epoxy-based hybrids using $\mathrm{TiO}_{2}$ nanoparticles prepared via a non-hydrolytic sol-gel route, Applied Organometallic Chemistry, 27 (2013) 673-677.
[36] S. Siddabattuni, T. P. Schuman, F. Dogan, Dielectric properties of polymer-particle nanocomposites influenced by electronic nature of filler surfaces, ACS Applied Materials and Interfaces, 5 (2013) 1917-1927.

[37] B. O'Regan, J. Moser, M. Anderson, M. J. Graetzel, Vectorial electron injection into transparent semiconductor membranes and electric field effects on the dynamics of light-induced charge separation, The Journal of Physical Chemistry, 94 (1990) 8720-8726.

[38] T. S. Radoman, J. V. Džunuzović, K. T. Trifković, T. Palija, A. D. Marinković, B. Bugarski, E. S. Džunuzović, Effect of surface modified $\mathrm{TiO}_{2}$ nanoparticles on thermal, barrier and mechanical properties of long oil alkyd resin-based coatings, Express Polymer Letters, 9 (2015) 916-931.

[39] I. A. Janković, Z. V. Šaponjić, E. S. Džunuzović, J. M. Nedeljković, New hybrid properties of $\mathrm{TiO}_{2}$ nanoparticles surface modified with catecholate type ligands, Nanoscale Research Letters, 5 (2010) 81-88.

Izvod

\section{NANOČESTICE TITAN-DIOKSIDA POVRŠINSKI MODIFIKOVANE IMINOM KAO PUNIOCI ZA EPOKSIDNU SMOLU}

Enis Džunuzović ${ }^{1 *}$, Stefan Ćirjakovićn ${ }^{1}$ Tijana Kovač², Miloš Tomić², Aleksandra Dapčević ${ }^{1}$, Jasna Džunuzović ${ }^{3}$

\footnotetext{
1 Tehnološko-metalurški fakultet, Univerziotet u Beogradu, Beograd, Srbija

2 Inovacioni centar, Tehnološko-metalurški fakultet, Univerzitet u Beogradu, Beograd, Srbija

3 Institut za Hemiju, tehnologiju i metalurgiju, Centar za hemiju, Grupa za polimere, Univerzitet u Beogradu, Beograd, Srbija
}

Površina nanočestica $\mathrm{TiO}_{2}$ modifikovana je "in situ" sintetisanim iminom na bazi 3,4-dihidroksibenzaldehida i oktadecilamina. Modifikovane $\mathrm{TiO}_{2}$ nanočestice su ispitivane primenom FTIR i UV-Vis spektroskopije, čime je potvrđeno formiranje "charge transfer" kompleksa između imina i površine $\mathrm{TiO}_{2}$ nanočestica preko reakcije Ti atoma na površini čestica sa hidroksilnim grupama modifikatora. Modifikovane $\mathrm{TiO}_{2}$ nanočestice su zatim iskorišćene kao punioci za pripremu nanokompozita na bazi epoksidne smole. Termička i mehanička svojstva pripremljenih nanokompozita su ispitana primenom dinamičko mehaničke analize, diferencijalne skenirajuće kalorimetrije, termogravimetrijske analize i ispitivanjem njihove tvrdoće. Dobijeni rezultati su pokazali da $\mathrm{TiO}_{2}$ nanočestice površinski modifikovane iminom ne utiču značajno na temperaturu ostakljivanja epoksidne smole, da usporavaju termooksidativnu degradaciju u prvom stupnju i da povećavaju tvrdoću umrežene epoksidne smole.
(ORIGINALNI NAUČNI RAD) UDK 66.017:678.686

Ključne reči: epoksi/ $\mathrm{TiO}_{2}$ nanokompoziti; površinska modifikacija; imin; termička svojstva; mehanička svojstva 